\title{
Blood Manganese Correlates with Brain Magnetic Resonance Imaging Changes in Patients with Liver Disease
}

\author{
Robert A. Hauser, Theresa A. Zesiewicz, Carlos Martinez, \\ Alexander S. Rosemurgy and C.W. Olanow
}

\begin{abstract}
Background: Chronic liver failure is associated with high signal abnormalities in the basal ganglia on T1-weighted magnetic resonance imaging of the brain. These abnormalities are strikingly similar to those seen following manganese intoxication. As dietary manganese is normally cleared by the liver, we hypothesize that hepatic dysfunction could lead to manganese overload and account for the MRI abnormalities seen in patients with chronic liver disease. Methods: We measured blood manganese concentrations in eleven patients with biopsy-proven hepatic cirrhosis and eleven healthy age and sex-matched controls. We also performed semi-quantitative measures of TI signal abnormalities on MRI in the patients with chronic liver disease. Results: Patients with cirrhosis had significantly higher blood manganese concentrations $(20.6 \pm 10.2 \mathrm{mcg} / \mathrm{L})$ than controls $(7.2 \pm 2.7, \mathrm{p}=.0013)$. In addition, semi-quantitative scores of $\mathrm{T} i$-weighted signal hyperintensity on MRI correlated with blood manganese concentration in patients with cirrhosis $(r=.65, p=.029)$. Conclusions: These findings demonstrate that chronic liver disease is associated with manganese overload and suggest that manganese is responsible for the $\mathrm{TI}$ weighted signal hyperintensity seen on MRI of patients with liver disease. As manganese intoxication is known to cause parkinsonism and an encephalopathy similar to those which occur with chronic liver disease, it is possible that manganese toxicity contributes to the development of these symptoms in liver damaged patients and that therapies which prevent or reduce manganese overload may have clinical benefit.
\end{abstract}

RÉSUMÉ: Le taux de manganèse sanguin est en corrélation avec les changements observés à l'imagerie par résonance magnétique chez les patients avec atteinte hépatique. Introduction: L'insuffisance hépatique chronique est associée à des anomalies du signal dans le noyau lenticulaire, le noyau caudé, l'avant-mur et le noyau amygdalien à l'imagerie par résonance magnétique avec pondération Tı du cerveau. Ces anomalies sont étonnammant semblables à celles observées dans l'intoxication au manganèse. Comme le manganèse de la diète est normalement éliminé par le foie, nous avons émis l'hypothèse qu'une dysfonction hépatique pourrait engendrer une surcharge en manganèse et être responsable des anomalies observées à I'IRM chez les patients atteints de maladie hépatique chronique. Méthodes: Nous avons mesuré la concentration de manganèse sanguin chez onze patients avec cirrhose hépatique prouvée par biopsie et onze contrôles sains, appariés pour l'âge et le sexe. Nous avons également réalisé des mesures semi-quantitatives des anomalies de signal Tl à l'IRM chez les patients atteints de maladie hépatique chronique. Résultats: Les patients atteints de cirrhose avaient des concentrations sanguines de manganèse significativement plus élevées $(20.6 \pm 10.2 \mathrm{mcg} / \mathrm{L})$ que les contrôles (7.2 $\pm 2.7, \mathrm{p}=.0013)$. De plus, les scores semi-quantitatifs de l'hyperintensité du signal pondéré T1 à l'IRM étaient corrélés avec les concentrations sanguines de manganèse chez les patients atteints de cirrhose $(r=.65, p=.029)$. Conclusions: Ces observations démontrent que la maladie hépatique chronique est associée à une surcharge en manganèse et suggèrent que le manganèse est responsable de l'hyperintensité du signal pondéré TI observé à l'IRM des patients atteints de maladie hépatique. Il est connu que l'intoxication au manganèse cause un parkinsonisme et une encéphalopathie semblables à ce qui est observé dans la maladie hépatique chronique. Il est donc possible que la toxicité par le manganèse contribue au développement de ces symptômes chez les patients avec atteinte hépatique et que les traitements qui préviennent ou diminuent la surcharge en manganèse puissent avoir un bénéfice clinique chez ces patients.

Can. J. Neurol. Sci. 1996; 23: 95-98

Chronic liver failure is associated with abnormal increased signal intensity in the globus pallidus (GP), putamen, substantia nigra (SN), and anterior pituitary on T1-weighted magnetic resonance imaging of the brain. ${ }^{1-3}$ The cause of these signal abnormalities is presently unknown. Tl-weighted signal hyperintensity can be associated with lipids, ${ }^{4}$ methemoglobin, ${ }^{5}$ melanoma, ${ }^{6}$ calcification, ${ }^{7}$ neurofibromatosis ${ }^{8}$ and manganese. ${ }^{9,10}$ However, only manganese (Mn) is known to cause an abnormal increase in Tl-weighted signal in the same distribution as observed in patients with chronic liver disease. We have hypothesized that patients with chronic liver disease may suffer Mn overload due to decreased hepatic elimination of normal dietary $\mathrm{Mn} .{ }^{11}$ To test this hypothesis, we compared blood Mn concentrations in patients with biopsyproven cirrhosis to those of healthy controls and evaluated the correlation between blood $\mathrm{Mn}$ concentration and the extent of T1-weighted signal hyperintensity on MRI.

From the Departments of Neurology (R.A.H., T.A.Z.), Radiology (C.M.), and Surgery (A.S.R.), University of South Florida. Tampa, Florida and the Department of Neurology, Mount Sinai School of Medicine (C.W.O.), New York, New York. RECEIVED AUGUST 1, 1995. ACCEPTED IN FINAL FORM DECEMBER 11, 1995. Reprint requests to: C. Warten Olanow, M.D., F.R.C.P.(C), Department of Neurology, Mount Sinai School of Medicine, I Gustave L. Levy Place, Box I137. New York, New York 10029 USA. 


\section{METHOdS}

Eleven patients with biopsy-proven cirrhosis underwent MRI of the brain and determination of blood Mn concentration. Blood Mn concentrations were also obtained in 11 age and sexmatched healthy controls. Consecutive patients with liver-biopsy confirmed cirrhosis were selected for the study from an ambulatory care hepatology clinic. Controls consisted of employees and family members of patients with no history of liver disease. All participants signed an informed consent. Blood Mn assays were performed by Smith Kline Beecham Clinical Laboratories using graphite furnace atomic absorption spectroscopy and were verified by repeat analysis. All blood samples were collected in an identical fashion and assayed by blinded technicians. A t-test was used to compare blood $\mathrm{Mn}$ concentrations between patients with cirrhosis and normal controls.

MRI studies of the brain were performed on a General Electric Signa 1.5 Tesla system. MR images were obtained in $\mathrm{T} 1$-weighted sagittal $(\mathrm{TR} / \mathrm{TE}=350 / 19 \mathrm{~ms})$, axial $(\mathrm{TR} / \mathrm{TE}=$ $500 / 19 \mathrm{~ms}$ ), and coronal (TR/TE $=500 / 19 \mathrm{~ms}$ ) planes; spin-echo axial (TR/TE $=3200 / 18 \mathrm{~ms}$ ) and coronal $(\mathrm{TR} / \mathrm{TE}=2400 / 30 \mathrm{~ms}$ ) planes; and, T2-weighted axial (TR/TE $=3200 / 126 \mathrm{~ms}$ ) and coronal $(2400 / 80 \mathrm{~ms})$ planes. MR images were evaluated by a blinded neuroradiologist (CM) using a semi-quantitative scale. Signal intensity was graded as normal (0), mildly abnormal $(1+)$, or markedly abnormal $(2+)$ in each of the GP, putamen, caudate nucleus, thalamus, SN, tectum, central pons, and anterior pituitary. For each patient, scores of T1-weighted signal hyperintensity in each of these regions were summed to yield a "T1score". Pearson's correlation coefficient was used to evaluate the relationship between blood Mn concentration and T1-score. Additional MRI abnormalities were recorded when present.

\section{RESULTS}

Eleven patients with biopsy-proven hepatic cirrhosis participated in the study (Table 1). Eight (73\%) were male. The mean age $( \pm S D)$ was $56.9 \pm 10.9$ years, and the average disease duration was $9.1 \pm 10.5$ years. The presumed cause of cirrhosis was alcohol abuse in 5 cases, infectious hepatitis in 3, and unknown in 3. None of the patients had Wilson's disease, Systemic Lupus Erythematosis, a history of prior parenteral nutrition, or were receiving dietary supplementation. Eight $(73 \%)$ had a functioning portal shunt.
Patients with cirrhosis had a mean blood Mn concentration of $20.6 \pm 10.2 \mathrm{mcg} / \mathrm{L}$. This compared with control individuals who had a mean blood Mn concentration of $7.2 \pm 2.7 \mathrm{mcg} / \mathrm{L}$. These values were significantly different using a t-test for samples with unequal variance $(p=.0013) .^{12}$

Abnormal T1-weighted signal hyperintensity was present on MRI in 10 of $11(91 \%)$ patients with chronic liver disease (Figure 1). Total T1 scores for individual patients are shown in Table 1 and regional distribution is illustrated in Table 2. Signal abnormality was most commonly observed in the SN and GP and was most pronounced in the GP. Abnormal T1-weighted signal hyperintensity in the putamen, tectum and anterior pituitary was also noted in some patients. Signal abnormalities were not observed in the caudate, thalamus or pons in any patient. No signal changes were detected in any of these regions on T2weighted or spin echo scans. Atrophy was present in 6 cases (55\%). In 5, the atrophy was generalized. In 1, atrophy was confined to the cerebellum. No other radiologic abnormalities were detected.

There was a significant correlation between total $\mathrm{T} 1$ score and blood $\mathrm{Mn}$ concentration as shown in Figure $2(r=0.65 ; p=.029)$. The $\mathrm{T} 1$ scores and $\mathrm{Mn}$ levels were normally distributed on the Wilks-Shapiro test, justifying assumptions for employing the Pearson correlation coefficient. Similar results were obtained with non-parametric analyses.

\section{Discussion}

We demonstrate significantly higher blood Mn concentrations in patients with biopsy-proven hepatic cirrhosis than healthy age and sex-matched controls. These findings are consistent with the findings of earlier investigators. ${ }^{11,13} \mathrm{We}$ also establish that blood $\mathrm{Mn}$ concentrations correlate with $\mathrm{Tl}$ signal abnormality on MRI in patients with chronic hepatic dysfunction. These findings support the notion that $\mathrm{Mn}$ accumulation accounts for the signal abnormalities seen on MRI in this patient population and raise the possibility that Mn may contribute to neurologic dysfunction in patients with chronic liver disease.

$\mathrm{Mn}$ is a trace metal which is essential for normal life, but can cause neurotoxicity at high concentrations. Within the brain, $\mathrm{Mn}$ accumulates in the GP and the pars reticularis portion of the $\mathrm{SN}^{14,15}$ where it is primarily localized within mitochondria and

Table 1: Baseline characteristics, MRI scores and blood Mn levels of 11 patients with biopsy-proven cirrhosis.

\begin{tabular}{|c|c|c|c|c|c|c|c|}
\hline Patient No. & Age (yrs) & Sex & Etiology & Duration (Yrs) & Shunt & Blood Mn (mcg/l) & Total T1 Score \\
\hline 1 & 40 & M & Hepatitis C & 10 & - & 45.0 & 7 \\
\hline 2 & 60 & M & ETOH & 10 & - & 20.1 & 7 \\
\hline 3 & 45 & $\mathbf{M}$ & Hepatitis C & 2 & + & 12.2 & 5 \\
\hline 4 & 53 & $\mathrm{~F}$ & UNK & 5 & + & 28.2 & 4 \\
\hline 5 & 38 & $\mathbf{M}$ & ETOH & 5 & + & 26.2 & 4 \\
\hline 6 & 65 & $M$ & UNK & 2 & - & 20.4 & 4 \\
\hline 7 & 69 & $\mathrm{~F}$ & UNK & 2 & + & 18.9 & 4 \\
\hline 8 & 56 & $\mathbf{M}$ & ETOH & 6 & + & 18.8 & 3 \\
\hline 9 & 67 & $\mathrm{~F}$ & Hepatitis C & 39 & + & 11.3 & 2 \\
\hline 10 & 61 & $\mathbf{M}$ & ETOH & 7 & + & 6.6 & 1 \\
\hline 11 & 65 & $\mathbf{M}$ & ETOH & 13 & + & 19.5 & 0 \\
\hline
\end{tabular}

$\mathrm{M}=$ male, $\mathrm{F}=$ female, $\mathrm{ETOH}=$ alcohol abuse, $\mathrm{UNK}=$ unknown. 

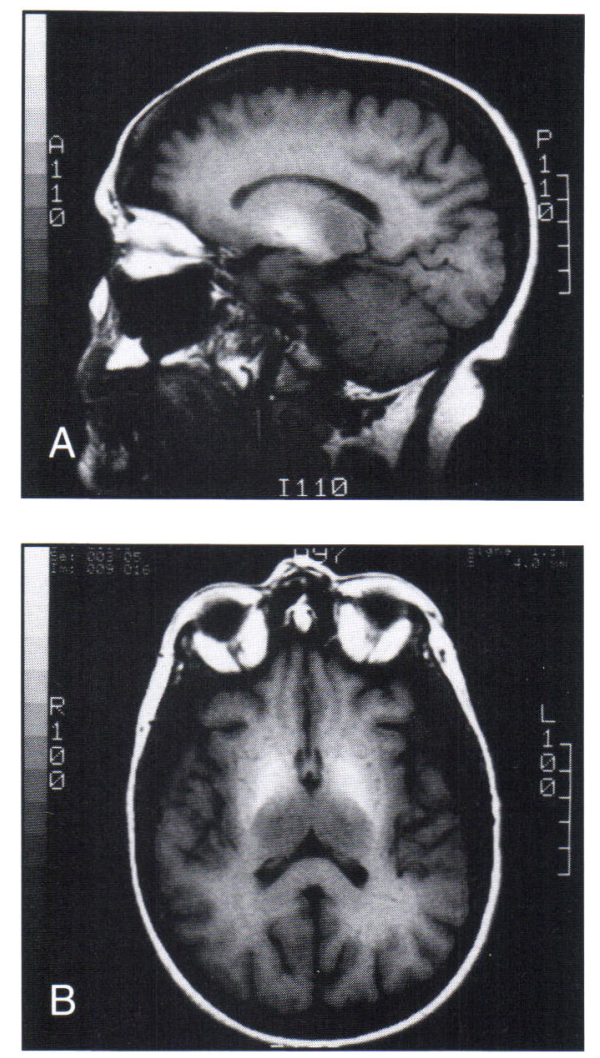

Figure 1: $T$ l-weighted sagittal and axial MRI of a patient with hepatic cirrhosis demonstrating signal hyperintensity in the globi pallidi.

Table 2: Distribution, frequency and severity of abnormal signal hyperintensity in patients with chronic liver disease.

\begin{tabular}{lcccccc}
\hline & GP & SN & Putamen & Tectum & Pituitary \\
Normal & 2 & 1 & 5 & 8 & 9 \\
Mild-Mod Abnormality & 2 & 8 & 6 & 2 & 2 \\
Marked Abnormality & 7 & 2 & 0 & 1 & 0 \\
Total Positive & 9 & 10 & 6 & 3 & 2 \\
Percent (\%) & 82 & 91 & 55 & 27 & 18 \\
\hline
\end{tabular}

serves as a cofactor for numerous enzymes. ${ }^{16} \mathrm{Mn}$ is ubiquitous in nature and widely distributed throughout the Earth's crust, water, and atmosphere. It is also normally ingested in food and water with an average daily intake of 2.6 to $3.0 \mathrm{mg} .{ }^{17}$ Only 1$3.5 \%$ of ingested $\mathrm{Mn}$ is systemically absorbed as it is rapidly cleared by the liver and excreted into bile. ${ }^{18-20}$ Indeed, bile duct obstruction in both patients and animal models has been demonstrated to cause a marked impairment of Mn elimination. ${ }^{21.22} \mathrm{Mn}$ intoxication has been reported to occur primarily as a consequence of industrial exposure. ${ }^{23}$ However, as $\mathrm{Mn}$ elimination occurs predominantly through the liver, we hypothesize that hepatic dysfunction could also lead to Mn overload. Our finding of increased blood $\mathrm{Mn}$ concentrations in patients with hepatic cirrhosis supports this concept.

$\mathrm{Mn}$ is a paramagnetic ion which shortens $\mathrm{Tl}$ on MRI in a concentration-dependent fashion. ${ }^{9}$ Parenteral administration of $\mathrm{Mn}$ to monkeys results in $\mathrm{Mn}$ accumulation and abnormal high

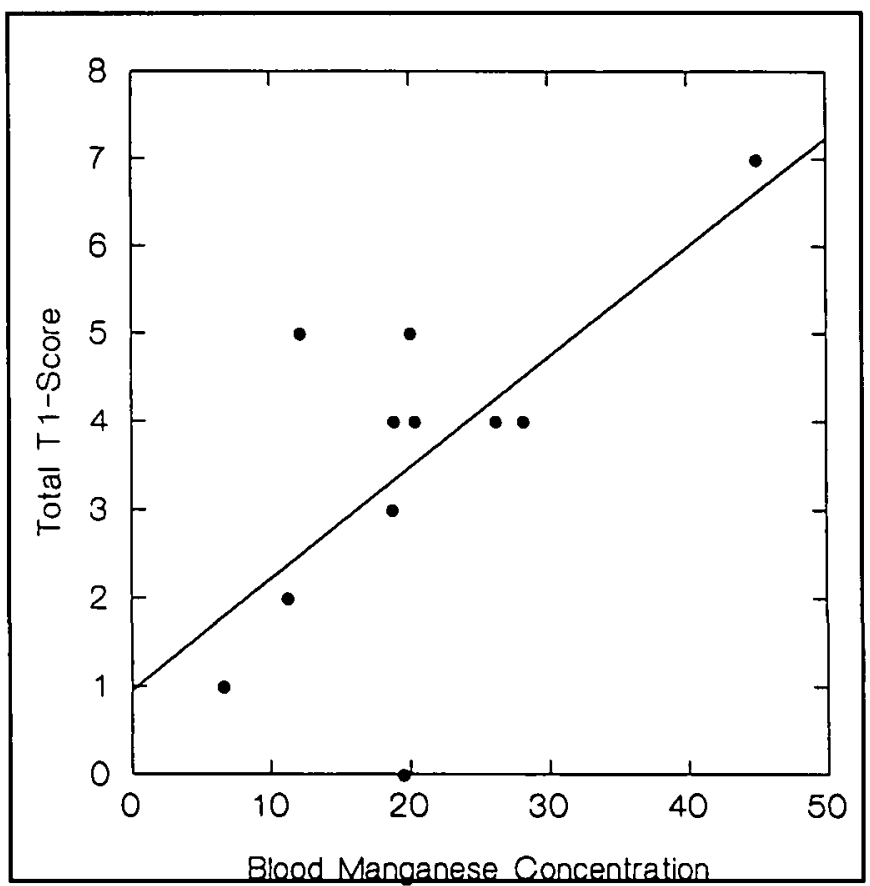

Figure 2: Blood Manganese concentration versus Total Tl-Score for II patients with hepatic cirrhosis $(r=0.65, p=.029)$.

signal intensity on T1-weighted MRI in the GP, SN, putamen, and anterior pituitary. ${ }^{9,24} \mathrm{~A}$ similar MRI pattern has been described in patients who were thought to have $\mathrm{Mn}$ intoxication due to: 1) long-term total parenteral nutrition containing $\mathrm{Mn},{ }^{25}$ 2) repair and recycling of railroad track containing a $\mathrm{Mn}$ steel alloy, ${ }^{26}$ and 3 ) chronic employment in a Mn smelting plant (personal observation $\mathrm{CWO}$ ). MRI findings have been reported to resolve following removal from the source of $\mathrm{Mn}$ exposure in both patients and animal models, ${ }^{9,26,27}$

The MRI abnormalties identified in patients with chronic liver disease are strikingly similar to those seen in association with $\mathrm{Mn}$ intoxication. In our cirrhotic patients, we noted abnormal Tl signal hyperintensity in the GP (82\%), SN (91\%), putamen $(55 \%)$, tectum $(27 \%)$, and anterior pituitary $(18 \%)$. Brunberg et al. ${ }^{1}$ reported abnormal increased signal on $\mathrm{T} 1$ weighted images in the GP (71\%), mesencephalon (40\%), putamen $(50 \%)$, tectum $(10 \%)$, and anterior pituitary $(80 \%)$ of 42 patients with chronic hepatic failure. Similarly, Kulisevsky et al. ${ }^{3}$ reported pallidal signal hyperintensity in $73 \%$ of cirrhotic patients and Inoue et al. ${ }^{2}$ noted pallidal signal hyperintensity in $56 \%$ of patients with portal-systemic encephalopathy. Interestingly, Tl-weighted signal abnormalities have been reported to resolve following treatment of hepatic encephalopathy. ${ }^{28}$ Thus the pattern and time course of resolution of signal abnormalities seen in patients with chronic liver disease is virtually identical to that observed in Mn intoxication.

$\mathrm{Mn}$ accumulation in the brain may have important clinical consequences for patients with chronic liver disease. $\mathrm{Mn}$ intoxication can lead to both encephalopathy and parkinsonism. ${ }^{29-33}$ In turn, encephalopathy and parkinsonism are both well recognized features of liver disease. ${ }^{34-36}$ It is therefore reasonable to consider that $\mathrm{Mn}$ accumulation may account for encephalopathy and parkinsonism in patients with chronic liver disease. It is noteworthy that 
Alzheimer type II astrocytes, which are characteristic findings in the GP and SN of patients with chronic liver disease, are also seen in these regions in Mn-intoxicated monkeys. ${ }^{24}$ Further support for this concept derives from the case an 8-year-old girl with developmental paucity of intrahepatic bile ducts who developed dystonia, tremor, and Tl-weighted signal abnormalities on MRI in association with an increase in blood Mn levels. ${ }^{37}$ Normalization of blood $\mathrm{Mn}$ levels following orthotopic liver transplantation was associated with resolution of neurological abnormalities and MRI changes. Additional studies are required to assess the relationship between Mn metabolism, MRI abnormalities, and clinical dysfunction in patients with liver disease. Ultimately, direct measurement of brain $\mathrm{Mn}$ concentration may be required to prove that $\mathrm{Mn}$ accumulates in the brain of patients with liver disease. Nonetheless, in the absence of a history of $\mathrm{Mn}$ exposure, signal hyperintensity in the GP and SN on T1weighted MRI should suggest the possibility of Mn accumulation due to chronic liver disease. If Mn does contribute to the development of neurologic signs and symptoms in cirrhotic patients, therapies that diminish $\mathrm{Mn}$ intake or enhance its elimination may prevent or reverse neurologic dysfunction.

Addendum: A paper on this topic has been recently published: (Kreiger D, Kreiger S, Jansen O, et al. Manganese and chronic hepatic encephalopathy. Lancet 1995; 346: 270-274.)

\section{REFERENCES}

1. Brunberg JA, Kanal E, Hirsch W, Van Thiel DH. Chronic acquired hepatic failure: MR imaging of the brain at $1.5 \mathrm{~T}$. Am J Neuroradiol 1991; 12: 909-914.

2. Inoue $\mathbf{E}$, Shinichi $\mathrm{H}$, Narumi $\mathrm{Y}$, et al. Portal-systemic encephalopathy: presence of basal ganglia lesions with high signal intensity on MR images. Radiology 1991; 179: 551-555.

3. Kulisevsky J, Pujol J, Junque C, et al. MRI pallidal hyperintensity and brain atrophy in cirrhotic patients: two different MRI patterns of clinical deterioration? Neurology 1993; 43: 2570-2573.

4. Young SW. Nuclear Magnetic Resonance Imaging. Basic Principles. New York: Raven Press, 1984.

5. Gomori JM, Grossman RI, Goldberg HI, et al. Intracranial hematomas: imaging by high-field MR. Radiology 1985; 157: 87-93.

6. Gomori JM, Grossman RI, Shields JA, et al. Choroidal melanomas: correlation of NMR spectroscopy and MR imaging. Radiology 1986; 158: 443-445.

7. Dell LA, Brown MS, Orrison WW, Eckel CG, Matwiyoff NA. Physiologic intracranial calcification with hyperintensity on MR imaging: case report and experimental model. Am J Neuroradiol 1988; 9: 1145-1148.

8. Mirowitz SA, Sartor K, Gado M. High-intensity basal ganglia lesions on TI-weighted MR images in neurofibromatosis. Am J Neuroradiol 1989; 10: 1159-1163.

9. Newland MC, Ceckler TL, Kordower JH, Weiss B. Visualizing manganese in the primate basal ganglia with magnetic resonance imaging. Exp Neurol 1989; 106: 251-258.

10. Shinotoh H, Snow B, Hewitt KA, et al. MRI and PET studies of manganese-intoxicated monkeys. Neurology 1995; 45: 1199 1204.

11. Hauser RA, Zesiewicz TA, Rosemurgy AS, Martinez C, Olanow CW. Manganese intoxication and chronic liver failure. Ann Neurol 1994; 36: 871-875.

12. Altman D. Practical Statistics for Medical Research. New York: Chapman and Hall, 1991.

13. Versieck J, Barbler F, Speecke A, Hoste J. Manganese, copper and zinc concentrations in serum and packed blood cells during acute hepatitis, chronic hepatitis and posthepatitic cirrhosis. Clin Chem 1974; 20: 1141-1145.
14. Larsen NA, Pakkenberg H, Damsgaard E, Heydorn K. Topographical distribution of arsenic, manganese, and selenium in the normal human brain. J. Neurol Sci 1979; 42: 407-416.

15. Bonilla E, Salazar E, Joaquin J, et al. The regional distribution of manganese in the normal human brain. Neurochem Res 1982; 7: 221-227.

16. Baruthio F, Guillard O, Arnaud J, Pierre F, Zawislak R. Determination of manganese in biological materials by electrothermal atomic absorption spectroscopy: a review. Clin Chem 1988; 34: 227-234.

17. Greger JL, Davis CD, Suttie JW, Lyle BJ. Intake, serum concentrations and urinary excretion of manganese by adult males. Am J Clin Nutr 1990; 51 : 457-461.

18. Greenberg DM, Copp DH, Cuthberston EM. Studies in mineral metabolism with aid of artificial radioactive isotopes; distribution and excretion particularly by way of bile, of iron, cobalt and manganese. J Biol Chem 1943; 147: 749-756.

19. Pollack S, George JN, Reba RC, Kaufmann RM, Crosby WH. The absorption of nonferrous metals in iron deficiency. J Clin Invest $1965 ; 44: 1470-1473$.

20. Klaassen $C D$. Billiary excretion of manganese in rats, rabbits and dogs. Toxicol Appl Pharmacol 1974; 29: 458-468.

21. Papavasiliou PS, Miller ST, Cotzias GC. Role of liver in regulating distribution and excretion of manganese. Am J Physiol 1966; 211:211-216.

22. Marchal G, Ni Y, Zhang X, et al. Mn-DPDP enhanced MRI in experimental bile duct obstruction. J Comput Assist Tomography 1993; 17: 290-296

23. Olanow CW, Calne DB, Chu NS, Perl D. Manganese-induced neurotoxicity. In: Calne DB et al., eds. Advances in Neurodegeneration II, Birkhauser Press, 1994: 53-62.

24. Olanow CW, Good PF, Shinotoh $\mathrm{H}$, et al. Manganese intoxication in the rhesus monkey; a clinical, pathological, and biochemical study. Neurology (In Press).

25. Mirowitz SA, Westrich JJ, Hisch JD. Hyperintense basal ganglia on T1-weighted MR images in patients receiving parenteral nutrition. Radiology 1991; 181: 117-120.

26. Nelson K, Golnick J, Korn T, Angle C. Manganese encephalopathy: utility of early magnetic resonance imaging. $\mathrm{Br} \mathrm{J}$ Indust Med 1993; 50: 510-513.

27. Mirowitz SA, Westrich TJ. Basal ganglia signal intensity alternations: reversal after discontinuation of parenteral manganese administration. Radiology 1992; 185: 535-536.

28. Watanabe A, Murakami J, Ando T, et al. Reduction of increased signal intensity in the basal ganglia on Tl-weighted MR images during treatment of hepatic encephalopathy. Internal Med 1993; 32: $10-14$

29. Mena I, Marin O, Fuenzalida S, Cotzias GC. Chronic manganese poisoning: clinical picture and manganese turnover. Neurology 1967; 17: 128-136.

30. Huang CC, Chu NS, Lu CS, et al. Chronic manganese intoxication. Arch Neurol 1989; 46: 1104-1106.

31. Cook DG, Fahn S, Brait KA. Chronic manganese intoxication. Arch Neurol 1974; 30: 59-64.

32. Huang CC, Lu CS, Chu NS, et al. Progression after chronic manganese exposure. Neurology 1993; 43: 1479-1483.

33. Calne DB, Chu NS, Hung CC, Lu CS, Olanow CW. Manganism and idiopathic parkinsonism: similarities and differences. Neurology 1994; 44: 1583-1586.

34. Sherlock S, Summerskill WHJ, White LP, Phear EA. Portal-systemic encephalopathy: neurological complications of liver disease. Lancet 1954; 267: 453-457.

35. Victor M, Adams RD, Cole M. The acquired (non-Wilsonian) type of chronic hepatocerebral degeneration. Medicine 1965; 44: 345396.

36. Read AE, Sherlock S, Laidlaw J, Walker JG. The neuro-psychiatric syndromes associated with chronic liver disease and an extensive postal-systemic collateral circulation. Quart J Med 1967; 36: 135-150.

37. Barron TF, Deveny AG, Mamourian AC. Symptomatic manganese neurotoxicity in a patient with chronic liver disease: correlation of clinical symptoms with MRI findings. Ped Neurol 1994; 10: 145-148. 